\title{
Yield and performance of sugarcane in on-farm interface with rubber in Brazil
}

\author{
Luís Fernando Guedes Pinto ${ }^{(1)}$, Marcos Silveira Bernardes ${ }^{(2)}$ and Antônio Roberto Pereira ${ }^{(3)}$
}

\begin{abstract}
(1)Instituto de Manejo e Certificação Florestal e Agrícola, Estrada Chico Mendes, no 185, Caixa Postal 411, CEP $13400-970$ Piracicaba, SP. E-mail: luisfernando@imaflora.org (2)Escola Superior de Agricultura Luiz de Queiroz (Esalq), Dep. de Produção Vegetal, Caixa Postal 9, CEP 13418-900 Piracicaba, SP. E-mail: msbernar@esalq.usp.br (3)Esalq, Dep. de Ciências Exatas. E-mail: arpereir@esalq.usp.br
\end{abstract}

\begin{abstract}
Agroforestry systems are indicated as an alternative for sugarcane (Saccharum officinarum) cultivation in Piracicaba, SP, Brazil, however there are not many field experiments on plant performance under these conditions in the world. The objective of this work was to assess crop yield and partitioning in a sugarcanerubber (Hevea brasiliensis) interface in on-farm conditions. The availability of irradiance for the crop along the interface was simulated and its effect over sugarcane dry matter production was tested. Crop yield was negatively affected by distance of the trees, but development and sucrose were not affected. Above ground dry matter increased from 16.6 to $51.5 \mathrm{t} \mathrm{ha}^{-1}$ from trees. Partitioning did not have a defined standard, as harvest index increased from 0.85 to 0.93 , but specific leaf area was not significant along the transect, ranging from 13.48 to $15.73 \mathrm{~m}^{2} \mathrm{~kg}^{-1}$. Light is the main factor of competition between the trees and the crop, but the relative importance of below ground interactions increases closer to the trees. Feasibility of the system depends on maturity of the trees and management strategies.
\end{abstract}

Index terms: Saccharum officinarum, Hevea brasiliensis, agroforestry systems, light, partitioning.

\section{Produção e desempenho de cana-de-açúcar em interface de campo com seringueira}

\begin{abstract}
Resumo - Sistemas agroflorestais são indicados como alternativa para o cultivo de cana-de-açúcar (Saccharum officinarum) em Piracicaba, SP, Brasil, porém, há falta de experimentos sobre o desempenho da cultura nestas condições. O objetivo deste trabalho foi avaliar a produção e partição da cultura em uma interface cana-deaçúcar/seringueira (Hevea brasiliensis) em condição de campo comercial. Simulou-se a disponibilidade de irradiância para a cultura ao longo da interface e testou-se seu efeito sobre a produção final de matéria seca da cana-de-açúcar. A produção da cultura foi afetada de forma negativa pela distância das árvores, mas o desenvolvimento e o teor de sacarose não foram afetados. A matéria seca acima do solo aumentou de 16,6 para 51,5 t ha-1, a partir das árvores. A partição não apresentou um padrão definido, pois o índice de colheita aumentou de 0,85 para 0,93, contudo a área foliar específica não apresentou alteração significativa, com variação de 13,48 a 15,73 m² $\mathrm{kg}^{-1}$. A luz é o principal fator de competição entre a árvore e a cultura, mas a importância relativa das interações abaixo do solo aumenta próximo das árvores. A viabilidade deste sistema depende da maturidade das árvores e de estratégias de manejo.
\end{abstract}

Termos para indexação: Saccharum officinarum, Hevea brasiliensis, sistemas agroflorestais, luz, partição.

\section{Introduction}

Agroforestry systems are an alternative for sugarcane (Saccharum officinarum) production in Piracicaba, SP, Brazil, because they may combine high yields with soil and biodiversity conservation. Rubber (Hevea brasiliensis) was suggested as potential tree specie for alley cropping systems combined with sugarcane in this region (Pinto et al., 2003). However, there are not many field trials assessing plant growth and yield of this crop in agroforestry systems. On-farm research has a key role to play in the understanding and development of agroforestry systems (Rao \& Coe, 1991), and it may be used for diagnosis of constraints and opportunities, selection of research priorities and evaluation of component response and interactions in the lack of controlled experiments. An effective method for detecting competition in this situation is to measure crop and tree yields along a transect across the tree crop interface (Ong, 1996).

The objectives of this work were to measure and to evaluate yield and partitioning of sugarcane in an 
interface with rubber trees and to investigate key interactions in this interface as well as the feasibility of a sugarcane-rubber alley cropping system.

\section{Material and Methods}

The field was located at São José Farm $\left(22^{\circ} 15^{\prime} \mathrm{S}\right.$, $47^{\circ} 45^{\prime} \mathrm{W}, 650 \mathrm{~m}$ a.m.s.l.), near Piracicaba, SP, Brazil, where a commercial sugarcane field interfaces a rubber tree area. Local climate is classified as Cwa, according to Köppen classification (wet subtropical, with rainy summer and dry winter). Mean annual temperature is $21.1^{\circ} \mathrm{C}$ and mean annual rainfall is $1,257 \mathrm{~mm}$. The sugarcane-rubber tree interface was in a flat area of Chromic Ferralsol soil (FAO Classification), well drained and moderately deep with sandy loam texture. Rubber trees rows were $\mathrm{N}-\mathrm{S}$ orientated with the sugarcane field on the West side. Tree plantation and crop field were $6.6 \mathrm{~m}$ apart separated by a land path.

The rubber tree field (RRIM 600 clone) was planted in 1983, at 7x3 m row spacing. The sugarcane field (SP83 2847 variety) was planted on March 16, 2001, with $1.4 \mathrm{~m}$ inter-row spacing. Fertilizer application rate at planting was at $120 \mathrm{~kg} \mathrm{ha}^{-1} \mathrm{~N}$ and $144 \mathrm{~kg} \mathrm{ha}^{-1} \mathrm{~K}_{2} \mathrm{O}$. The first sugarcane cycle would take 18 months and the next ratoons would take 12 months.

A sugarcane-rubber tree interface of $40 \mathrm{~m}$ was selected. In the rubber tree outer-row, 11 consecutive trees were sampled. For each tree, total height, with Haga hipsometer, diameter at breast height; canopy width in the direction of the sugarcane field and leaf area index were measured. A canopy analyzer LI-COR LAI 2000 was used, in the morning in a cloudy day, to measure the leaf area index.

Four transects in the sugarcane field were sampled on May 22, 2002. Six positions, at 7.5, 9.0, 12.5, 16.0, 21.5 , and $36.5 \mathrm{~m}$ from the first rubber tree row in each transect were sampled. Taking the average tree height as reference, the relative distances of the sampling positions were: $0.58,0.70,0.97,1.24,1.66$, and 2.82 . The sugarcane sampling was adapted from Machado et al. (1982). In each position, all the tillers in $2 \mathrm{~m}$ of the row were cut down, and number of tillers, plant and stalk heights, and fresh above-ground biomass (stalk, cabbage, green and dry leaves) were measured. Two tillers per position and two samples of dry leaves of the whole experiment were separately weighted for dry matter analysis. From the sampled stalks, the number of internodes was counted and two more stalks were sampled for sucrose and fiber analysis. For determination of specific leaf area (SLA) and leaf area index (LAI), the dry weight of one disc of $76.51 \mathrm{~mm}^{2}$ from ten leaves per position was collected and determined. Crop data were subjected to analysis of variance (ANOVA, at $\alpha=0.05$ ) to identify significant effects from tree distances. Variables with significant effect were submitted to regression analysis.

To investigate the importance of light interactions in the tree crop interface, an irradiance simulation model adapted by Bernardes et al. (1998) was used. The model calculates the irradiance available for row crops according to the distance and canopy geometry of a tree row: $\mathrm{Ir}=\mathrm{I}_{0} / 2(\sin (\operatorname{arc} \tan ((\mathrm{d}-(\mathrm{cW} . \mathrm{cW} / \mathrm{d})) / \mathrm{hr})+\mathrm{s})+1)$, in which $\mathrm{Ir}$ is the irradiance available for the intercrop $\left(\mathrm{MJ} \mathrm{m}^{-2} \mathrm{~d}^{-1}\right)$; $\mathrm{d}$ is the distance from the trees $(\mathrm{m}) ; \mathrm{I}_{0}$ is the irradiance on a horizontal surface above the tree canopy ( $\left.\mathrm{MJ} \mathrm{m}^{-2} \mathrm{~d}^{-1}\right)$; cw is canopy width (m); $\mathrm{s}$ is slope of the land (radians); and hr is the relative height of trees (m), obtained from the difference of tree and crop heights.

By the model, the relative irradiance available for sugarcane in each position was calculated according to the tree distance and tree and sugarcane heights, considering that the relative irradiance was $100 \%$ at the furthest position from the tree row. Afterwards, with biomass data collected in the field, the relationship between the relative irradiance and crop relative dry matter production was tested with linear regression analysis. Based on the variation of above ground dry matter along the transect, zones of homogeneous crop growth were identified. Finally, using again the irradiance model and the regression equation of relative dry matter and relative tree distance, the relative irradiance was estimated and the relative dry matter for each zone, according to the value of the position free of competition, was calculated.

\section{Results and Discussion}

Biometric dimensions of rubber trees are shown in Table 1. Sugarcane growth variables (dry matter, stalk weight, height, number of tillers, LAI and internodes length) had significant changes along the transect, and were medium to highly correlated with tree distance (Tables 2 and 3 and Figure 1).

Table 1. Mean and standard deviation of growth variables of rubber trees in an on-farm interface with sugarcane.

\begin{tabular}{lr}
\hline Parameter & \multicolumn{1}{c}{ Value } \\
\hline Height $(\mathrm{m})$ & $12.94 \pm 1.900$ \\
Diameter $(\mathrm{DBH}-\mathrm{cm})$ & $19.82 \pm 2.410$ \\
Canopy width $(\mathrm{m})$ & $4.60 \pm 0.510$ \\
Plantation leaf area index $\left(\mathrm{m}^{2}\right.$ leaf $\mathrm{m}^{-2}$ soil $)$ & $1.58 \pm 0.061$ \\
\hline
\end{tabular}


Table 2. Mean and standard deviation of sugarcane variables measured along transects from rubber trees.

\begin{tabular}{|c|c|c|c|c|c|c|c|}
\hline \multirow[t]{2}{*}{ Variable } & \multirow[t]{2}{*}{ ANOVA } & \multicolumn{5}{|c|}{ Position at } & \multirow[b]{2}{*}{$36.0 \mathrm{~m}$} \\
\hline & & $7.5 \mathrm{~m}$ & $9.0 \mathrm{~m}$ & $12.5 \mathrm{~m}$ & $16.0 \mathrm{~m}$ & $21.5 \mathrm{~m}$ & \\
\hline Above ground dry matter $\left(\mathrm{t} \mathrm{ha}^{-1}\right)$ & * & $16.60 \pm 9.00$ & $21.30 \pm 5.30$ & $36.8 \pm 17.60$ & $47.10 \pm 7.90$ & $41.50 \pm 7.50$ & $51.50 \pm 7.20$ \\
\hline Fresh stalk $\left(\mathrm{Mg} \mathrm{ha}^{-1}\right)$ & * & $53.75 \pm 29.25$ & $67.46 \pm 18.65$ & $129.59 \pm 34.36$ & $167.32 \pm 33.19$ & $146.49 \pm 20.27$ & $160.63 \pm 20.02$ \\
\hline Tillers $\mathrm{m}^{-2}$ & * & $4.75 \pm 0.96$ & $5.25 \pm 1.89$ & $8.00 \pm 1.63$ & $8.50 \pm 2.08$ & $8.25 \pm 0.95$ & $8.75 \pm 0.95$ \\
\hline Leaf area index $\left(\mathrm{m}^{2}\right.$ leaf $\mathrm{m}^{-2}$ soil $)$ & * & $1.91 \pm 0.36$ & $2.11 \pm 0.43$ & $3.37 \pm 1.63$ & $4.39 \pm 0.56$ & $4.75 \pm 1.19$ & $3.46 \pm 0.26$ \\
\hline Total height $(\mathrm{m})$ & * & $2.39 \pm 0.47$ & $3.17 \pm 0.15$ & $3.82 \pm 0.22$ & $4.80 \pm 0.14$ & $4.97 \pm 0.15$ & $4.55 \pm 0.26$ \\
\hline Stalk height $(\mathrm{m})$ & * & $1.78 \pm 0.13$ & $2.44 \pm 0.12$ & $3.07 \pm 0.22$ & $3.65 \pm 0.34$ & $3.62 \pm 0.12$ & $3.31 \pm 0.18$ \\
\hline Number of internodes & ns & $18.00 \pm 4.00$ & $21.00 \pm 1.50$ & $20.00 \pm 1.00$ & $22.00 \pm 2.00$ & $21.00 \pm 0.50$ & $20.00 \pm 1.00$ \\
\hline Length of internodes (m) & * & $0.10 \pm 0.03$ & $0.11 \pm 0.005$ & $0.15 \pm 0.01$ & $0.17 \pm 0.02$ & $0.17 \pm 0.01$ & $0.16 \pm 0.02$ \\
\hline $\operatorname{SLA}\left(\mathrm{m}^{2} \mathrm{~kg}^{-1}\right)$ & ns & $13.48 \pm 2.33$ & $13.78 \pm 2.32$ & $15.73 \pm 0.67$ & $14.56 \pm 0.62$ & $15.07 \pm 1.97$ & $13.93 \pm 1.13$ \\
\hline Trash - dry leaves $\left(\mathrm{kg} \mathrm{m}^{-2}\right)$ & $*$ & $0.44 \pm 0.23$ & $0.65 \pm 0.23$ & $1.27 \pm 0.44$ & $1.74 \pm 0.39$ & $1.39 \pm 0.39$ & $1.13 \pm 0.20$ \\
\hline Dry weight of green leaves/stalk & $* *$ & $0.12 \pm 0.04$ & $0.09 \pm 0.03$ & $0.06 \pm 0.006$ & $0.07 \pm 0.01$ & $0.09 \pm 0.01$ & $0.05 \pm 0.009$ \\
\hline Harvest index & $*$ & $0.85 \pm 0.04$ & $0.89 \pm 0.02$ & $0.91 \pm 0.01$ & $0.90 \pm 0.02$ & $0.89 \pm 0.005$ & $0.93 \pm 0.008$ \\
\hline Fiber weight/stalk weight (\%) & ns & $11.60 \pm 0.55$ & $10.91 \pm 0.87$ & $10.42 \pm 0.55$ & $10.92 \pm 0.73$ & $11.02 \pm 0.37$ & $10.63 \pm 0.38$ \\
\hline Sucrose weight/stalk weight (\%) & ns & $12.34 \pm 0.58$ & $11.60 \pm 2.26$ & $10.13 \pm 0.47$ & $12.36 \pm 1.88$ & $11.44 \pm 0.87$ & $11.29 \pm 0.55$ \\
\hline
\end{tabular}

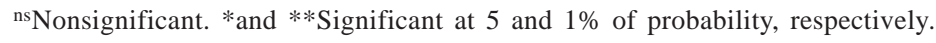

Development was not affected by tree distance, as internode number was not statistically different along the transect (Tables 2 and 3). However, partitioning was affected, as both harvest index and the dry green leaf weight/dry stalk weight ratio were significantly different. Regression analysis showed a tendency of increase of the harvest index and decrease of the previous ratio along the transect (Tables 2 and 3). Specific leaf area also did not show significant change. Sucrose concentration and fiber weight of the stalk were also independent of the field position.

It was possible to identify three homogenous zones of influence of the trees over crop growth along the transect, regarding irradiance availability. These would be in the interval of the positions 1-2, 3 and 4-6 (Table 4). Correlation between relative dry matter and relative irradiance, with high significance level, was verified (Figure 2).

Sugarcane growth was influenced by distance from the rubber trees. Data showed that effect of trees over crop growth reached a distance of more than 1.5 their height. Rubber trees $14 \mathrm{~m}$ tall affected beans yield up to the distance of $10 \mathrm{~m}$ (Righi, 2000). Nevertheless, this and the cited experiments were done with mature trees, where maximum intensity of competition with the crop is expected (Ong et al., 2000). Thus, sugarcane yield could be higher before rubber trees reach maturity in an alley cropping system. Management strategies as canopy and root pruning would also minimize tree competition effects.

The decrease in crop growth closer to the trees can be explained by the reduction of radiation, and
Table 3. Type of non linear regression of sugarcane variables in relation to rubber tree distance.

\begin{tabular}{llc}
\hline Variable & Type of regression & $\mathrm{r}^{2}$ \\
\hline Above ground dry matter $\left(\mathrm{t} \mathrm{ha}^{-1}\right)$ & Logarithmic & 0.57 \\
Fresh stalk $\left(\mathrm{t} \mathrm{ha}^{-1}\right)$ & Logarithmic & 0.68 \\
Tillers $\mathrm{m}^{-2}$ & Logarithmic & 0.53 \\
Leaf area index $\left(\mathrm{m}^{2}\right.$ leaf $\mathrm{m}^{-2}$ soil $)$ & Logarithmic & 0.45 \\
Total height $(\mathrm{m})$ & Logarithmic & 0.86 \\
Stalk height $(\mathrm{m})$ & Logarithmic & 0.82 \\
Length of internodes $(\mathrm{m})$ & Logarithmic & 0.64 \\
Trash - dry leaves $\left(\mathrm{kg} \mathrm{m}^{-2}\right)$ & Logarithmic & 0.44 \\
Dry weight of green leaves/stalk & Negative exponential & 0.33 \\
Harvest index & Logarithmic & 0.45 \\
\hline
\end{tabular}

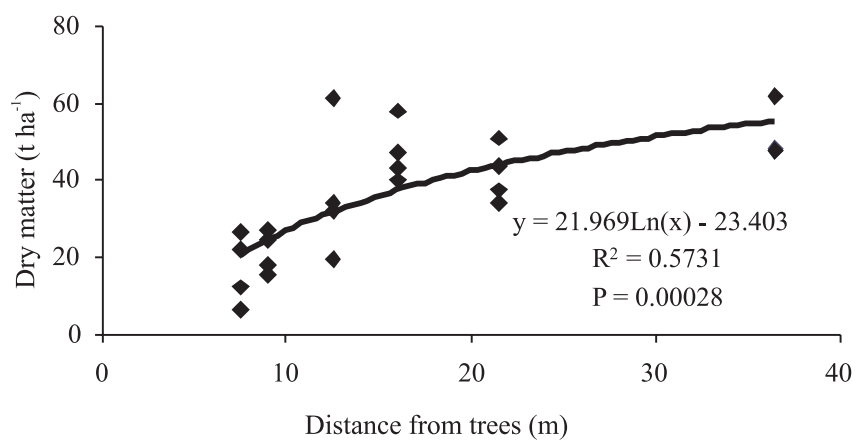

Figure 1. Non-linear regression of sugarcane dry matter in relation to the distance from rubber trees.

air and soil temperatures in shaded areas (Monteith et al., 1991). Robertson et al. (1996) found that sugarcane biomass was linearly related with cumulative radiation interception by the crop canopy, which depends on crop LAI. That agrees with the significant linear regression found between dry matter and LAI along the transects (Figure 3). 
Significant changes in partitioning agree with Brenner (1996) statement that shade may affect this process in some crops. Values of leaf weight ratio, harvest index and specific leaf area are in the range of values obtained by Machado et al. (1982) in Brazil. However, results are contrary to the findings of Pinto et al. (2005) in a sugarcane-eucalyptus interface in the same region of this study. They found significant changes of development variables along the transect and not significant values of partitioning variables. Sucrose concentration and fiber weight of the stalk were also independent of the field position. Results are similar to the findings of Muchow et al. (1996), who obtained fresh stalk sucrose concentration of $0.125 \mathrm{~g} \mathrm{~g}^{-1}$ fresh matter (or $12.5 \%$ ). However, an increase in sucrose concentration in the shaded part of the transect due to the reduction in air temperature was expected (Irvine, 1983).

Dry matter obtained in the position not affected by the trees $\left(51.5 \mathrm{t} \mathrm{ha}^{-1}\right)$ was similar to $53 \mathrm{t} \mathrm{ha}^{-1}$, found by Machado et al. (1982) in monocropping, in Brazil. However, values were lower than the reported by Muchow et al. (1996) for sugarcane growth in irrigated and high input conditions in a tropical region of Australia.

There was correlation with high significance $(\mathrm{p}<0.01)$ in the linear regression between relative dry matter and estimated relative irradiance (Figure 2). It suggests that shade of trees over crop is the major factor affecting sugarcane performance. The same was verified by Righi (2000) in a bean-rubber interface in Brazil. However, in that study, higher

Table 4. Relative distance from rubber trees, estimated relative irradiance available for the crop, relative mean sugarcane dry weight and zone per position measured.

\begin{tabular}{ccccc}
\hline Position & $\begin{array}{c}\text { Relative } \\
\text { distance }\end{array}$ & $\begin{array}{c}\text { Relative } \\
\text { irradiance }\end{array}$ & $\begin{array}{c}\text { Relative } \\
\text { dry weight }\end{array}$ & Zone \\
\hline 1 & 0.58 & 0.70 & 0.32 & 1 \\
2 & 0.70 & 0.78 & 0.41 & 1 \\
3 & 0.97 & 0.88 & 0.71 & 2 \\
4 & 1.24 & 0.94 & 0.91 & 3 \\
5 & 1.66 & 0.97 & 0.81 & 3 \\
6 & 2.82 & 0.99 & 1.00 & 3 \\
\hline
\end{tabular}

correlation and a relation close to $1: 1$ between variables was verified. This condition was due to the trial irrigation and heavy fertilization, which minimized the effect of belowground interactions. The reduction of the relation between relative irradiance and relative dry matter could be caused by the strong effect of shade to sugarcane growth, a $\mathrm{C}_{4}$ plant with great photosynthetic response to radiation intensity. Additionally, the regression with linear coefficient smaller than one indicated that there is no dry matter production from a certain distance from trees, even with radiation availability. Besides light competition, the effect of belowground competition, not considered in the model, and more relevant close to the trees is suggested.

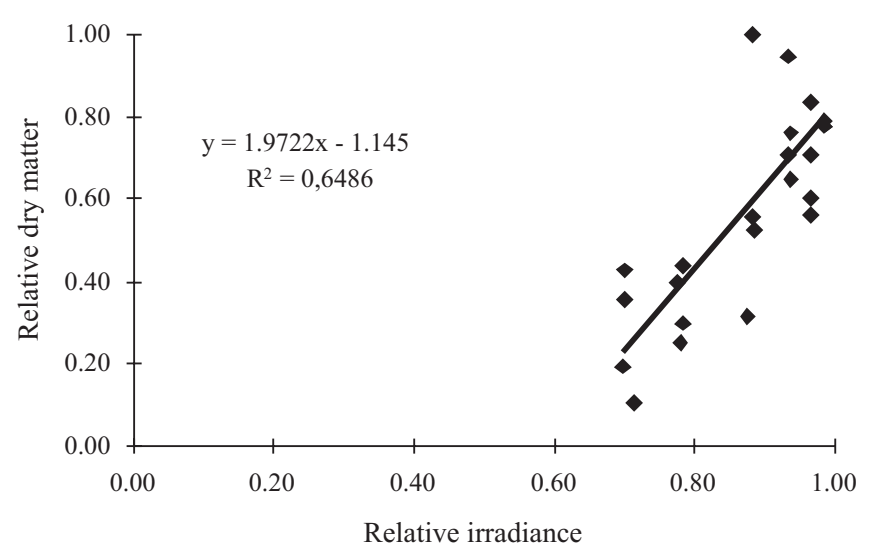

Figure 2. Linear regression of relative irradiance and sugarcane above ground relative dry matter.

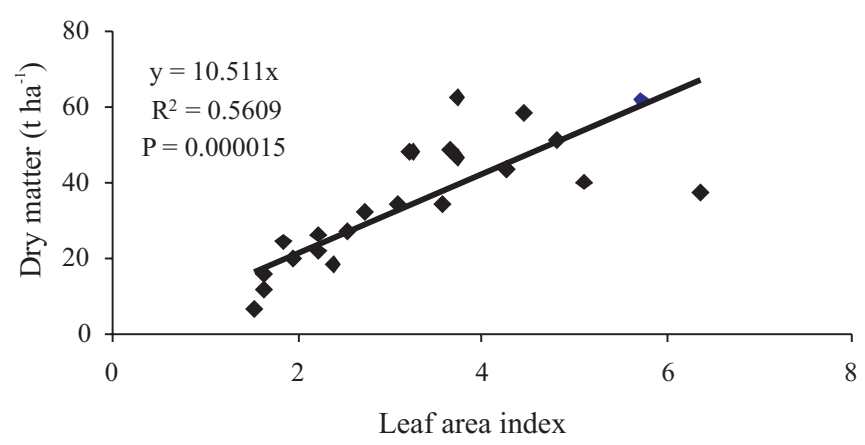

Figure 3. Linear regression between leaf area index and above ground sugarcane dry matter. 


\section{Conclusions}

1. Sugarcane dry matter and yield are negatively affected by distance of rubber trees.

2. Crop partitioning, development and sucrose are not affected by the trees.

3. Light is the main factor of competition between the trees and the crop, but the relative importance of belowground interactions increases closer to the trees.

\section{Acknowledgements}

To Fapesp, for the scholarship; to Francisco Spatti, on behalf of São José Farm; to the colleagues from the Crop Sciences graduate program and technicians of the Crop Sciences Department of Esalq.

\section{References}

BERNARDES, M.S.; GOUDRIAAN, J.; DOURADO NETO, D.; CÂMARA, G.M.S. Tree-crop interactions in agroforestry system of rubber with soybean and maize. In: EUROPEAN SOCIETY FOR AGRONOMY CONGRESS, 5., 1998, Nitra. Short communications. Nitra: ESA, 1998. v.2, p.125-126.

BRENNER, A.J. Microclimatic modifications in agroforestry. In: ONG, C.K.; HUXLEY, P. (Ed.). Tree-crop interactions: a physiological approach. Wallingford: CAB International; ICRAF, 1996. p.159-188.

IRVINE, J.E. Sugarcane. In: SYMPOSIUM ON POTENTIAL PRODUCTIVITY OF FIELD CROPS UNDER DIFFERENT ENVIRONMENTS, 1983, Los Baños. Proceedings. Los Baños, Philippines: International Rice Research Institute, 1983. p.361-381.

MACHADO, E.C.; PEREIRA, A.R.; FAHL, J.I.; ARRUDA, H.V.; CIONE, J. Índices biométricos de duas variedades de cana-deaçúcar. Pesquisa Agropecuária Brasileira, v.17, p.1323-1329, 1982.
MONTEITH, J.L.; ONG, C.K.; CORLETT, J.E. Microclimatic interactions in agroforestry systems. Forest Ecology and Management, v.45, p.31-44, 1991.

MUCHOW, R.C.; ROBERTSON, M.J.; WOOD, A.W. Growth of sugarcane under high input conditions in tropical Australia. II. Sucrose accumulation and commercial yield. Field Crops Research, v.48, p.27-36, 1996.

ONG, C.K. A framework for quantifying the various effects of treecrop interactions. In: ONG, C.K.; HUXLEY, P. (Ed.). Tree-crop interactions: a physiological approach. Wallingford: $\mathrm{CAB}$ International; ICRAF, 1996. p.1-24.

ONG, C.K.; BLACK, C.R.; WALLACE, J.S.; KHAN, A.A.H.; LOTT, J.E.; JACKSON, N.A.; HOWARD, S.B.; SMITH, D.M. Productivity, microclimate and water use in Grevillea robusta-based agroforestry systems on hillslopes in semi-arid Kenya. Agriculture, Ecosystems and Environment, v.80, p.121-141, 2000.

PINTO, L.F.G.; BERNARDES, M.S.; SPAROVEK, G. Feasibility of cultivation of sugarcane in agroforestry systems. Scientia Agricola, v.60, p.489-493, 2003.

PINTO, L.F.G.; BERNARDES, M.S.; STAPE, J.L.; PEREIRA, A.R. Growth, yield and system performance simulation of a sugarcaneeucalyptus interface in a sub-tropical region of Brazil. Agriculture, Ecosystems and Environment, v.105, p.77-86, 2005.

RAO, M.R.; COE, R.D. Measuring crop yields in on-farm agroforestry studies. Agroforestry Systems, v.15, p.275-289, 1991.

RIGHI, C. Interações ecofisiológicas acima e abaixo do solo em um sistema agroflorestal de seringueira (Hevea brasiliensis) e feijoeiro (Phaseolus vulgaris). 2000. 121p. Dissertação (Mestrado) - Escola Superior de Agricultura Luiz de Queiroz, Piracicaba.

ROBERTSON, M.J.; WOOD, A.W.; MUCHOW, R.C. Growth of sugarcane under high input conditions in tropical Australia. I. Radiation use, biomass accumulation and partitioning. Field Crops Research, v.48, p.11-25, 1996. 